\title{
STRATEGI PENCIPTAAN MATERI HUMOR: ANALISIS TRANSITIVITAS
}

\author{
Rawuh Yuda Yuwana \\ yuda.ryy@gmail.com \\ Universitas Sebelas Maret Surakarta
}

\begin{abstract}
The purpose of this research was to find out strategies in creating Indonesian humour materials. This research is a descriptive-qualitative research. In collecting the data, the researcher used listening technique by taping and writing. In analyzing data, this research applied equalizing reference method by comparing technique to support codification, reduction, presentation, and interpretation such as work design of qualitative research. As the result of this research, it has been found 8 strategies in creating Indonesian humour materials, namely: (1) exploiting the common truth that people already know, (2) changing constituents with his language experience, (3) putting false pronouns deliberately, (4) conveying something incomplete, (5) diverting different languages, (6) providing an unrelated response at all, (7) exploiting the language gap to distort its meaning, and (8) conveying something unnatural, absurd, even impressed controversy.
\end{abstract}

Keywords: humour; strategy; transitivit; language experience

\section{PENDAhuluan}

Terciptanya humor yang berkualitas sangat tergantung pada kecerdasan dan kreativitas pembicara atau penulis dalam mencari celah dari suatu makna kata. Hal ini penting, mengingat humor yang menyoroti bentuk fisik tidak mendidik, sehingga humor yang cerdas dan kreatif dengan mempermainkan penggunaan makna kata serta tanpa memojokkan pihak lain menjadi lebih diminati di masyarakat. Lawakan yang sederhana dan disampaikan dengan bahasa yang terkesan terstruktur, tetapi mengandung logika absurd yang menggoda pendengar untuk berpikir sebelum tertawa merupakan sebuah daya tarik tersendiri dalam humor.

Tujuan dari penelitian ini untuk menemukan strategi-strategi materi humor Indonesia melalui pengalaman berbahasa komedian atau pelawak. Oleh karena itu diperlukan teori humor untuk menandai suatau klausa apakah di dalamnya terdapat humor dan tidak. Selanjutnya teori dari sistemik fungsional linguistik yang lebih terfokus pada teori transitivitas akan digunakan untuk menemukan perubahan konstituen yang dilakukan komedian dengan pengalaman berbahasa yang dimilikinya.

Beberapa penelitian terdahulu yang terkait dengan penelitian ini di antaranya Sudaryanto (2012) yang meneliti keterlibatan aspek pragmatik dalam membangun humor. Kemudian, Marwan (2013) membahas penggunaan bahasa humor dalam buku karya Alain Le Saux sedangkan Fauzan (2015) menganalisis penggunaan transitivitas dalam teks berita di TV One. Sementara itu, Juramli (2015) menelisik dominasi sistem transitivitas dalam teks Daqaaiqul Akhbar. Selanjutnya, Purwanti (2006) meneliti data verbal yang dikaji secara sosiopragmatik dan fokus mendeskripsikan penyimpangan aspek pragmatik dalam humor sedangkan Agusrawati (2016) memfokuskan penelitiannya untuk mengetahui jenisjenis ambiguitas makna dalam dalam novel, iklan, humor dalam Bahasa Inggris. Sementara itu, (Sukardi, dkk. 2016) yang menelaah penyimpangan makna dan perubahan konstituen dalam materi humor Cak Lontong. Penelitian 
humor dari sudut pandang linguistik lainnya adalah dilakukan Rustono (1998) yang menggunakan pendekatan pragmatik dengan data verbal berupa dialog yang difokuskan pada pendeskripsian pemanfaatan aspek kebahasaan untuk melakukan pelanggaran-pelanggaran pada prinsip kerja sama dan prinsip kesantunan.

Dari seluruh penelitian terkait yang sudah diulas, diketahui bahwa penelitian yang dilakukan cenderung berkutat pada ranah pragmatik. Meskipun beberapa di antaranya juga melibatkan aspek semantik dalam kajiannya, tetapi tetap saja aspek semantik ini hanya dijadikan dasar untuk membuktikan adanya penyimpangan prinsip-prinsip pragmatik. Oleh karena itu, hal penting yang harus diperhatikan dari sekian banyak penelitian linguistik dalam ranah humor dari sudut pandang pragmatik ini adalah belum adanya kajian mengenai strategi penyajian materi humor khususnya dalam bahasa Indonesia.

Menurut Suhadi (1989) humor akan menghadirkan kelucuan bergantung pada pemilihan bunyi/intonasi, makna, dan pertentangan atau penyelewengan dari suatu aturan, kebiasaan atau budaya tertentu. Humor timbul karena audiens menemukan hal-hal yang tidak terduga dari yang disampaikan komedian hingga menimbulkan tawa saat secara tiba-tiba akaibat adanya ketidaksesuaian antara konsep dengan realita sebenarnya. Humor berfungsi sebagai pemelihara sense of self, yaitu cara sehat yang dilakukan seseorang untuk merasakan 'jarak' antara dirinya dengan masalah, cara untuk menghindarkan diri dari masalah dan memandang masalah dari sudut pandang berbeda(Sugiarto 2016).

Struktur umum penyajian humor terdiri dari tiga bagian. Yang pertama adalah orientasi, yang merupakan pembuka materi humor yang memperkenalkan hal yang akan disoroti. Kemudian event, yang merupakan penjelas terjadinya suatu peristiwa dalam rangkaian materi humor. Terakhir, twist, yaitu ending atau akhir dari sebuah cerita yang yang biasanya sengaja dipelintir atau dibelokkan untuk mendapatkan kelucuan. Kata hingga kalimat dapat menimbulkan intepretasi makna ganda dan bisa dimanfaatkan untuk melakukan teknik belokan mendadak (unexpected turns) atau membiarkannya tetap dalam kerancuan tanpa penyelesaian.

Humor terbagi menjadi dua macam, yaitu humor verbal dan nonverbal. Humor verbal adalah humor yang dipresentasikan dengan bahasa, misalnya berupa tulisan atau ujaran. Sedangkan humor non-verbal dengan gerak-gerik atau gambar, misalnya dalam pantonim atau karikatur (Rustono, 1998). Humor verbal dapat diteliti secara linguistik karena unsur-unsur pembentuk kelucuannya berupa permainan bahasa. Permainan bahasa dalam hal ini lebih tepat diartikan sebagai penyimpangan makna bahasa dalam suatu ungkapan. Penyimpangan makna tersebut akan membuat pengalaman yang disampaikan oleh penutur menghasilkan kejanggalan dan ketidakberterimaan karena konstituen pembangun mengalami perubahan. Lebih jauh, ungkapan yang awalnya dipahami dengan lazim bisa berubah menjadi pengalaman yang absurd. Hal yang demikian akan menimbulkan kelucuan melalui ketakterdugaan atau keanehan dari pengalaman berbahasa yang disampaikan.

Kualitas humor dipengaruhi kecerdasan dan kreativitas pembicara atau penulis dalam memanfaatkan celah makna bahasa. Humor yang memanfaatkan unsur bahasa ini akan lebih menarik dan mendidik dibanding humor yang menyinggung bentuk fisik. Penelitian ini bertujuan untuk menemukan strategi-strategi apa saja yang dilakukan komedian Indonesia dalam menyajikan materi humornya. Pada umumnya, pengkajian humor menggunakan pendekatan semantik, pragmatik, dan psikologi. Selain itu, hal lain yang juga perlu diperhatikan adalah konsep pembangun humor dan 
perwujudan pengalaman berbahasa dalam konstituen pembangun klausa.

Menurut Soedjatmiko (1992), terdapat dua teori kebahasaan tentang humor, yakni teori semantik humor dan teori pragmatik humor. Teori semantik humor memanfaatkan keambiguan dengan mempertentangkan makna pertama yang berbeda dari makna kedua, sedangkan teori pragmatik humor memanfaatkan penyimpangan prinsip-prinsip tindak ujar. Oleh karena penelitian ini fokus terhadap strategi materi humor berdasarkan pengalaman berbahasa, maka teori semantik humor yang lebih tepat digunakan dalam penelitian ini.

Dalam menciptakan humor, makna merupakan unsur bahasa yang sering dimanfaatkan oleh pembicara atau penulis. Hal ini terjadi karena keleluasaan dan banyaknya peluang dalam pemaknaan berbahasa. Seperti yang dikemukakan oleh Poerdawarminta (2002) makna dalam sebuah bahasa memiliki beberapa kemungkinan arti yang belum begitu jelas. Ketidakjelasan dapat terjadi karena banyaknya variasi arti yang terkandung dalam penggunaan bahasa yang terjadi karena adanya kelonggaran-kelonggaran yang yang berasal dari hubungan komponenkomponen tertentu.

Parera (2004) dan Ullman (2012) menjelaskan bahwa kata mempunyai sejumlah segi yang berbeda-beda sesuai konteks tempat kata tersebut digunakan. Dalam hal ini, konteks bisa menjelaskan makna mana yang sedang pembicara atau penulis ingin sampaikan saat kata tersebut memiliki makna lebih dari satu. Ditemukannya makna yang diinginkan pembicara atau penulis akan mengkhususkan makna yang sesuai dan menghilangkan makna yang tidak sesuai dalam konteks kalimat tertentu.

Melengkapi teori-teori linguistik yang sudah ada, Halliday (2004) memperkenalkan teori linguistik fungsional sistemik (SFL) yang memiliki tiga fungsi utama, yaitu metafungsi ideasional, interpersonal, dan tekstual. Metafungsi ideasional berupa penggunaan bahasa untuk mengekspresikan pengalaman yang terkandung dalam makna eksperiensial yang merealisasikan pengalaman dan makna logikal yang memperlihatkan hubungan atau keterkaitan unsur berdasarkan nalar (logic) seperti hubungan partisipan-proses-sirkumstan, induk-pewatas, dan hubungan-hubungan yang tertuang sebagai konjungsi. Selanjutnya, metafungsi interpersonal adalah pemakaian bahasa untuk merealisasikan interaksi, memperlihatkan bagaimana sikap bertahan, mengusulkan, merealisasikan tentang kewajiban dan kecenderungan, serta mengekspresikan sikap. Sementara itu, metafungsi tekstual berupa penggunaan bahasa untuk mengorganisasikan pengalaman serta makna logis dan interpersonal ke dalam suatu koherensi bahasa baik lisan maupun tulis.

Halliday (2004) menekankan bahwa pengalaman internal berada dalam alam sadar, reaksi, pemahaman, dan persepsi, di samping tindakan linguistiknya dalam berbicara dan memahami. Selanjutnya, transitivitas adalah sistem yang menguraikan pengalaman sebagai jenis proses yang terkait dengan partisipan dan sirkumstan. Pada proses tersebut makna dapat dipahami pada level klausa yang terdiri atas: (1) proses, (2) partisipan, dan (3) sirkumstan. Proses mengacu pada aktivitas yang terjadi dalam klausa. Dalam tata bahasa tradisional dan formal disebut verba atau kata kerja. Proses diklasifikasikan ke dalam material, mental, verbal, perilaku (mental dan verbal), eksistensial, dan relasional (atributif dan indenfikasi). Partisipan adalah orang atau benda yang terlibat dalam proses. Tergantung jenis prosesnya, partisipan dalam suatu klausa bisa berbeda-beda, ada aktor (actor), gol (goal), resipien, klien, range, senser, fenomenon, behaver, receiver, verbiage, sayer, inisiator (initiator), inducer, attributor, assigner, eksisten, carrier (pembawa), atribut, sesuatu (token), dan nilai (value). Sirkumstan merupakan 
lingkungan tempat proses yang melibatkan partisipan, yang dibedakan menurut sudut, eksten, lokasi (tempat dan waktu), cara (alat, kualitas, dan perbandingan), sebab (alasan, tujuan, kondisi, dan atas nama), penemanan, masalah, dan peran. Inti pengalaman adalah proses, maka dalam tataran klausa, proses menentukan partisipan dan secara tidak langsung menentukan sirkumstan dengan tingkat probabilitasnya. Oleh karenanya pada level analisis klausa, pusat makna ada pada proses.

Menurut penjelasan Santosa (2003), dalam tataran klausa akan terlihat sistem atau struktur klausa dalam merealisasikan makna ideasionaleksperiensial. Gramatika yang merealisasikan struktur klausa yang mempresentasikan makna ideasionaleksperensial ini disebut transitivitas. Struktur klausa dan kelompok yang mempresentasikan makna ideasionallogikal mempunyai sistem gramatika yang disebut klausa kompleks dan kelompok.Selanjutnya, struktur klausa yang merealisasikan makna interpersonal mempunyai gramatika yang disebut sistem mood dan struktur mood. Dan struktur klausa yang merealisasikan makna tekstual (terutama sistem informasinya) mempunyai sistem gramatika yang disebut struktur tema, dan struktur informasi lama dan baru.Ketiga sistem klausa ini bekerja secara simultan dalam merealisasikan tekstur suatu teks di dalam konteks tertentu.

\section{Metode Penelitian}

Beberapa hal yang harus diperhatikan dalam pelaksanaan penelitian adalah metode, data, tujuan, dan manfaat penelitian. Metode penelitian diperlukan untuk mencapai sasaran penelitian karena ini merupakan tata cara untuk merumuskan ide dan pikiran yang didasarkan pada pendekatan ilmiah. Metode yang digunakan dalam penelitian ini adalah metode deskriptif-kualitatif. Hal ini dikarenakan data yang dianalisis bukan berupa angka-angka, lambanglambang atau koefisien mengenai hubungan antarvariabel. Metodologi kualitatif merupakan prosedur penelitian yang menghasilkan data deskriptif berupa kata-kata tertulis atau lisan dari orangorang dan perilaku yang dapat diamati. Pendekatan ini diarahkan pada latar dan individu tersebut secara holistik (Sugiyono 2004; Aminuddin 1990; Moleong 2004). Data dan sumber data dalam penelitian ini ditentukan berdasarkan kebutuhan yang berkaitan erat dengan masalah penelitian. Data dalam penelitian ini berupa satuan linguistik (kata, frasa, klausa, dan kalimat) humor komedian yang mengandung penyimpangan makna dan perubahan konstituen. Penelitian ini tidak akan mengambil data dari satu sumber dengan jangka waktu tertentu. Penelitian ini akan mengambil data dari beberapa sumber seperti meme, kumpulan humor, materi Indonesia Lawak Klub, Waktu Indonesia Bercanda dan stand-up comedy yang sebagain di antaranya berasal dari tayangan televisi. Data dikumpulkan dengan menggunakan metode simak dengan teknik dasar sadap dan teknik lanjutan catat. Penggunaan metode simak dalam penyediaan data yang diwujudkan dalam teknik dasar sadap dan teknik lanjutan catat ini bukanlah proses yang terpisah (Mahsun 2014). Selanjutnya data dianalisis menggunakan metode padan referensial dengan teknik hubung banding (Mahsun, 2014), yaitu menghubung-bandingkan penyimpangan makna dan perubahan konstituen dengan referennya untuk mendukung dilakukannya kodifikasi, reduksi data, penyajian data, dan intepretasi sesuai dengan kerangka kerja penelitian kualitatif (Sugiyono 2014).

\section{HASIl dAN PEMBAhASAN}

Dari analisis data yang telah dilakukan pada penelitian ini, ditemukan adanya beberapa strategi penciptaan materi humor yang sering digunakan oleh para komedian di 
Indonesia. Berikut ini beberapa contohnya.

\section{Analisis 1}

Materi

Jangan suka ngurusiorang lain, karena belum tentu orang itu ingin kurus.

Struktur

Orientasi/Event(O/E) : Jangan suka ngurusiorang lain

Twist (T)

: karena belum tentu orang itu ingin kurus

Transitivitas

Klausa (1): Jangan suka ngurusiorang lain (ngurusi: proses perilaku mental)

Klausa (2): karena belum tentu orang itu ingin kurus (kurus: verbiage)

Pada contoh di atas, orientasi dan event berada dalam satu klausa. Dalam orientasi dan event, komedian menyampaikan saran untuk tidak suka ikut campur atau memikirkan urusan orang lain dengan menggunakan kata ngurusi. Ini merupakan hal wajar yang menjadi kebenaran umum disampaikan siapapun karena memang sebaiknya kita tidak ikut campur urusan orang lain. Komedian sudah memastikan makna kata ngurusi akan diinterpretasikan dengan 'ikut campur', karena konteks kalimat mengarahkan kata ngurusi pada makna tersebut. Namun, pada bagian twist, komedian menjelaskan alasannya yang dengan serta-merta dan tiba-tiba mengubah makna kata ngurusi menjadi 'membuat jadi kurus'. Komedian memanfaatkan kemungkinan pembentukan kata ngurusi yang bisa dibentuk dari kata dasar 'urus' dan 'kurus'. Komedian terkesan memaksakan dua makna berbeda yang sebenarnya tidak saling berhubungansama sekali.

Jadi, dalam twist humor ini terjadi penyimpangan makna yang dipicu oleh komedian.Penyimpangan makna ini mennimbulkan ketidakwajaran atau keabsurdan yang berakibat tidak nyambung-nya pengalaman yang disampaikan melalui bahasa. Berubahnya pemaknaan kata hingga klausa yang berdampak pada munculnya makna lain akan berimbas pada perubahan konstituendalam struktur transitivitas klausa.

Dari sudut pandang transitivitas, kata ngurusi pada klausa 1 merupakan verba yang merepresentasikanproses perilaku mental, sedangkan kata kurus yang terdapat pada klausa 2 merupakan adjektiva yang termasuk ke dalam kelompok verbiage. Jadi dalam hal ini, terjadi perubahan konstituen dari klausa pertama ke klausa kedua dengan proses yang berbeda pula, yaitu klausa 1 menggunakan proses perilaku mental sedangkan klausa 2 menggunakan proses mental saja.

\section{Analisis 2}

Materi

Jangan mengarungi lautan karena karung lebih cocok untuk beras.

Struktur

$\mathrm{O} / \mathrm{E}$ : Jangan mengarungi lautan

$\mathrm{T}$ : karena karung lebih cocok untuk beras

Transitivitas

(1) Jangan mengarungi lautan(mengarungi: proses materi)

(2) karena karung lebih cocok untuk beras (karung: pembawa)

Pada ungkapan ini, orientasi dan event juga berada dalam satu bagian yang sama. Di sini komedian menyampaikan larangan untuk tidak berlayar mengarungi lautan.Kata 'lautan' digunakan sebagai upaya untuk mengunci intepretasi makna pendengar terhadap kata 'mengarungi'. Komedian sudah memastikan makna kata 'mengarungi' akan diinterpretasikan dengan 'berlayar'. Pernyataan untuk tidak mengarungi lautan adalah sesuatu yang tidak bisa diterima karena nenek moyang orang Indonesia dikenal sebagai pelaut yang tangguh.Akan tetapi, di dalam twist, komedian kemudian menjelaskan alasannya dengan mengubah acuan 
makna kata 'mengarungi'. Kata 'mengarungi yang semula berarti 'berlayar' dibelokkan maknanya menjadi 'memasukan ke dalam karung'. Pengubahan makna kata 'mengarungi' ini dikuatkan dengan kata 'beras'. Di sini komedian memanfaatkan kemungkinan pembentukan kata 'mengarungi' yang bisa berasal dari kata dasar 'arung' atau 'karung'.

Apabila kalimat di atas diuraikan berdasarkan sistem transitivitasnya, pada klausa 1, kata 'mengarungi' merupakan verba yang merepresentasikan proses materi. Sementara kata 'karung' pada klausa 2, merupakan nomina yang berfungsi sebagai pembawa. Jadi dalam hal ini, terjadi perubahan konstituen di antara kedua klausa dengan proses yang berbeda, yaitu pada klausa 1 berupa proses materi sedangkan pada klausa 2 berupa proses relasional-atributif.

\section{Analisis 3}

Materi

Membaca setengah jam per hari itu sama dengan membaca 30 menit per hari.

Struktur

O/E : Membaca setengah jam per hari itu sama dengan

$\mathrm{T}$ : membaca 30 menit per hari

Transitivitas

(1) Membaca setengah jam per hari(setengah jam: sirkumstan)

(2) itu sama dengan

(3) membaca 30 menit per hari menit: sirkumstan)

Pada orientasi dan event di atas, komedian membuat perbandingan yang wajar tentang durasi membaca dalam satu hari dengan frasa 'sama dengan'. Perbandingan yang dimaksud terdapat pada bagian twist, yaitu antara durasi 'setengah jam' dan '30 menit' yang kesamaannya diakui semua orang. Jadi di sini komedian tidak menyimpangkan makna, fungsi, dan konstituen kata.

Pada ketiga klausa, komedian tidak mengubah makna kata apapun dan hanya menyampaikan kebenaran umum yang bersifat sinonimi. Jadi dalam hal ini, tidak terjadi perubahan konstituen pada dua klausa yang berisi perbandingan, yaitu klausa 1 dan klausa 3, karena keduanya sama-sama menggunakan proses materi 'membaca'.

\section{Analisis 4}

Materi

Di Inggris dan Amerika orangnya tidak pernah minum dan mandi dengan air karena di sana air itu adalah udara.

Struktur

O/E : Di Inggris dan Amerika orangnya tidak pernah minum dan mandi dengan air

$\mathrm{T}$ : karena di sanaair itu adalah udara

Transitivitas

(1) Di Inggris dan Amerika orangnya tidak pernah minum dan mandi dengan air(air: goal)

(2) karena di sana air itu adalah udara (air: pembawa)

Pada kalimat ini, orientasi dan event juga berada dalam satu klausa. Di dalamnya, komedian memberikan pernyataan yang tidak wajar dan seakan menentang kebenaran umum, yaitu tentang adanya orang-orang yang tidak minum dan mandi dengan air. Pernyataan ini tentu saja tidak bisa diterima oleh akal sehat karena manusia tidak bisa lepas dengan air di manapun ia berada. Di sini, komedian sudah mengunci interpretasi audiens dengan menekankan kata 'minum dan mandi' yang akan membuat orang berpikir bahwa kata 'air' yang dimaksudkan adalah 'air' dalam bahasa Indonesia yang mengacu pada suatu jenis zat cair. Pada bagian twist, komedian kemudian menjelaskan maksud pernyataannya bahwa istilah 'air' yang dimaksud adalah air dalam bahasa Inggris yang berarti 'udara'. Ini merupakan sebuah kebenaran umum tentang kata air dalam bahasa Inggris yang berarti 'udara'. Komedian memanfaatkan celah dalam bentuk 
penggunaan dua istilah dari bahasa yang berbeda, yakni bahasa Indonesia dan bahasa Inggris, yang memiliki perbedaan makna.

Pada klausa 1, kata 'air' merupakan nomina yang berfungsi sebagai goal sedangkan pada klausa 2, kata air merupakan nomina yang berfungsi sebagai pembawa. Jadi dalam hal ini, terjadi perubahan konstituen dengan proses yang berbeda, yaitu pada klausa 1 dengan proses materi dan pada klausa 2 dengan proses relasional atributif.

\section{Analisis 5}

Materi

Yang penting bagi pemimpin adalah ' $\mathrm{n}$ ' karena tanpa ' $\mathrm{n}$ ' pemimpin hanyalah pemimpi.

Struktur

$\mathrm{O} / \mathrm{E}$ : Yang penting bagi pemimpin adalah 'n'

$\mathrm{T}$ : karena tanpa ' $\mathrm{n}$ ' pemimpin hanyalah pemimpi.

Transitivitas

(1) Yang penting bagi pemimpin adalah ' $n$ '

(2) karena tanpa 'n' pemimpin hanyalah pemimpi

Pada contoh ini, orientasi dan event juga berada dalam satu klausa.Di sini komedian membuat pernyataan yang tidak wajar mengenai bagian penting dari seorang pemimpin yaitu 'n'. Hal ini menimbulkan pertanyaan bagi audiens karena biasanya yang penting bagi pemimpin adalah leadership, kebijaksanaan, ketegasan dan lain-lain yang berhubungan dengan sifat kepemimpinan. Selain itu, komedian juga menggunakan kata 'bagi' yang merupakan preposisi untuk makhluk hidup. Pada bagian twist, komedian langsung menjelaskan maksud pernyataannya bahwa dalam kata 'pemimpin', huruf 'n' adalah sesuatu yang penting karena tanpa huruf ini 'pemimpin' hanya akan jadi 'pemimpi'. Di sini jelas bahwa maksud komedian adalah ejaan kata 'pemimpin' bukan rujukannya atau orang yang memimpin. Adalah sebuah kebenaran umum, bahwa kata 'pemimpin' yang tersusun dari huruf-huruf $\mathrm{p}, \mathrm{e}, \mathrm{m}, \mathrm{i}, \mathrm{m}$, $\mathrm{p}$, i, dan $\mathrm{n}$, jika tanpa huruf 'n' maka hanya akan jadi kata 'pemimpi' dengan makna yang jauh berbeda.

Pada klausa 1, kata 'pemimpin' merupakan nomina yang berfungsi sebagai pembawa, sedangkan pada klausa 2, kata yang sama merupakan nomina yang berfungsi sebagai sesuatu. Jadi dalam hal ini, terjadi perubahan konstituen di antara dua klausa dengan proses yang berbeda, yaitu klausa 1 menggunakan proses relasionalatributif sedangkan klausa 2 prosesnya berupa relasional-identifikasi.

\section{Analisis 6}

Materi

Jangan membalas budi karena belum tentu Budi melakukannya.

Struktur

O/E : Jangan membalas budi

$\mathrm{T}$ : karena belum tentu Budimelakukannya

Transitivitas

(1) Jangan membalas budi (budi: goal)

(2) karena belum tentu

Budimelakukannya (Budi: aktor)

Pada orientasi dan event di atas, komedian melarang audiens untuk membalas budi. Larangan ini menimbulkan ketidakselarasan atau ketidakwajaran di mata audiens karena 'membalas budi' adalah perbuatan baik di masyarakat. Pada bagian twist, komedian kemudian memberikan alasannya dengan menyimpangkan makna awal 'budi' yang berarti 'kebaikan' atau 'jasa' menjadi 'Budi' yang merupakan nama orang.

Pada klausa 1, kata 'budi' merupakan sebuah nomina yang berfungsi sebagai goal. Sementara pada klausa 2, kata 'Budi' merupakan nomina yang berfungsi sebagai aktor. Jadi dalam hal ini, terjadi perubahan konstituen dari klausa 1 ke klausa 2 dengan proses yang masih sama, yaitu proses materi. 
Analisis 7

Materi

Anda tahu kenapa bom atom dijatuhkan di Hiroshima dan Nagasaki?Kalau tahu cerita dong.

Struktur

O/E : Anda tahu kenapa bom atom dijatuhkan di Hiroshima dan Nagasaki?

$\mathrm{T}$ : Kalau tahu cerita dong

Transitivitas

(1) Anda tahu(tahu: proses mental)

(2) kenapa bom atom dijatuhkan di Hiroshima dan Nagasaki?

(3) kalau tahu(tahu: proses mental)

(4) cerita dong

Pada orientasi sekaligus event di atas, komedian menanyakan sesuatu yang terkesan memberikan tebakan kepada lawan bicaranya.Ini merupakan sesuatu yang wajar jika seseorang ingin mengetahui kemampuan lawan bicaranya. Dalam hal ini, yang ditanya biasanya akan menunggu jawaban dari penanya sendiri. Namun, pada bagian twist, komedian justru memberikan pernyataan yang tidak wajar atau tidak nyambung, yaitu dengan meminta audiens menceritakan mengenai peristiwa yang ditanyakannya karena ternyata komedian sendiri juga tidak tahu menahu mengenai peristiwa tersebut.Pada kejadian ini, komedian tidak menuntaskan pernyataan yang dilontarkannya tanpa menyimpangkan makna ataupun mengubah konstituen kata.

Pada keseluruhan klausa di atas, komedian tidak mengubah makna kata apapun.Ia hanya mengajukan pertanyaan yang tidak dituntaskan dengan jawaban sebagaimana yang biasa dilakukan narasumber. Dengan kata lain, tidak ada perubahan konstituen pada keempat klausa diatas. Meskipun demikian, masing masing klausa memiliki proses yang berbeda, yakni klausa 1 dan 3 menggunakan proses mental, klausa 2 dengan proses materi, dan klausa 4 memakai proses perilaku-verbal.
Dari beberapa contoh hasil analisis di atas, tampak bahwa komedian menggunakan berbagai macam strategi dalam menciptakan materi humornya, yakni memanfaatkan kebenaran umum yang jelas orang sudah tahu (Analisi 1, 3, 4, dan 5), merubah konstituen dengan pengalaman berbahasanya (Analisis 1, 2, 4, 5, dan 6), sengaja salah menempatkan pronomina (Analisis 6), menyampaikan sesuatu yang tidak tuntas (Analisis 7). Selain itu, komedian juga mengalihfungsikan bahasa yang berbeda (Analisis 4), memberikan respon yang tidak nyambung (Analisis 1, 2, 4, 5, 6, dan 7). Sementara itu dalam hal pemaknaan, komedian sering memanfaatkan celah untuk menyimpangkan makna suatu kata (Analisis 1, 2, 4, 5, dan 6) dan juga menyampaikan sesuatu yang tidak wajar, absurd, dan bahkan terkesan kontroversial (Analisis 1, 2, 4, 5, 6, dan 7).

\section{KESIMPULAN}

Dari hasil penelitian ini diketahui bahwa komedian sedikitnya menggunakan 8 strategi dalam menciptakan materi humornya. Pertama, komedian sering memanfaatkan kebenaran umum yang jelas orang sudah tahu. Kedua, komedian juga merubah konstituen dengan pengalaman berbahasanya. Ketiga, komedian dengan sengaja salah menempatkan pronomina. Keempat, komedian menyampaikan sesuatu yang tidak tuntas. Kelima, komedian juga mengalihfungsikan bahasa yang berbeda. Keenam, komedian juga sering memberikan respon yang tidak nyambung atau tidak berhubungan sama sekali. Ketujuh, dalam hal pemaknaan, komedian berupaya menggiring audiens ke suatu makna lalu memanfaatkan celah untuk menyimpangkan maknanya. Kedelapan, komedian menyampaikan sesuatu yang tidak wajar, absurd, bahkan terkesan kontroversial.

Lebih lanjut, dalam strategi materi humor, komedian tidak terlalu memperhatikan struktur humor. 
Komedian pada dasarnya lebih menekankan pada pengalaman berbahasa yang dimilikinya yang terimplementasi dengan seringnya mengungkap kebenaran umum, menyampaikan sesuatu yang tidak wajar, mempermainkan makna dan merubah konstituen. Komedian tidak menyinggung masalah fisik dalam materi humornya. Hal ini membuat materi humornya lebih bisa diterima masayarakat dan membuatn komedian naik daun di dunia komedi Indonesia.

\section{DAfTar Pustaka}

Agusrawati, Sri. 2016. Ambiguitas dalam Bahasa Inggris (Studi Kasus dalam Novel, Iklan, Humor dalam Bahasa Inggris). (Tesis) Yogyakarta: Universitas Gadjah Mada

Aminuddin.1990. Pengembangan Penelitian Kualitatif dalam Bidang Bahasa dan Sastra. Malang: Yayasan Asih Asah Asuh

Alwi, H. dkk. 2003. Tata Bahasa Baku Bahasa Indonesia. Balai Pustaka: Jakarta.

Attardo, S. 1994. Linguistic Theories of Humor. New York: Mounte de Gruyter

CompZone 08. 2017. 75 Meme Kocak Cak Lontong. Website.memekocak.my.id. Diakses dari <https://www.memekocak. my.id/2017/04/75-meme-kocak-caklontong.html> (Januari-Agustus 2017)

Fauzan, U. 2015. "Transitivitas Teks Berita Tvone Mengenai Kasus Luapan Lumpur Sidoarjo". Pedagogik, 8 (1)

Febriyanti, Revitasari. 2016. Kumpulan Meme Cak Lontong.

Website.hype.idntimes.com. Diakses dari < https://hype.idntimes.com/humor/ vita/ kumpulan-meme-cak-lontong/full > (Januari-Agustus 2017)

Halliday, MAK. 1985. "Systemics Background" dalam JD Benson\& WS Greaves (pen.). Systemic Perspective on Discourse: 1-15. Norwood: Ablex Publishing

Halliday, MAK. 2004. An Introduction To Functional Grammar. New York: Oxford University Press Inc.

Juramli. 2015. "Transitivitas pada Teks Daqaaiqul Akhbar Telaah Fungsi Ideasional dalam Kajian Linguistik
Fungsional Sistemik”. Litera Jurnal Bahasa dan Sastra, 1 (2)

Mahsun. 2014. Metode Penelitian Bahasa Tahapan Strategi Metode dan Tekniknya. Jakarta: PT Rajagrafindo Persada

Marwan, I. 2013. "Wujud Kebahasaan dalam Wacana Humor: Kajian Semiotika”. Jurnal Al-Tsaqafa. 10 (1)

Moleong, Lexy J. 2013. Metodologi Penelitian Kualitatif. Bandung: PT Remaja Rosdakarya

Netmediatama Official Youtube Channel.Waktu Indonesia Bercanda. Diakses dari <https://www.youtube.com/ channel/UCuqQUkQwKB1f-ZB3b2tBM $\mathrm{mQ}>$ (Januari-Agustus 2017)

Parera, Jos D. 2004.Teori Semantik (Edisi Kedua). Jakarta: Erlangga.

Poerdawarminta, WJS. 2002. Kamus Besar Bahasa Indonesia.Jakarta: Balai Pustaka

Purwanti, Eko. 2006. Wacana Humor dalam Komedi Extravaganza: Kajian Sosiopragmatik (Tesis). Yogyakarta: Universitas Gadjah Mada

Rustono.1998. Implikatur Percakapan sebagai Penunjang Pengungkapan Humor di dalam Wacana Humor Verbal Lisan Berbahasa Indonesia (Disertasi). Yogyakarta: Universitas Negeri Yogyakarta

Santosa, Riyadi. 2003. Semiotika Sosial: Pandangan terhadap Bahasa. Surabaya: Pustaka Eureka.

Soedjatmiko, W. 1992. PELLBA 5. Yogyakarta: Kanisius

Sudaryanto. 2012. Wacana Humor Verbal Tulis Gus Dur: Kajian Sosiopragmatik. (Tesis) Yogyakarta: Universitas Negeri Yogyakarta.

Suhadi, MA. 1989. Humor itu Serius: Pengantar Ilmu Humor. Jakarta: Pustakakarya Grafikatama.

Sugiarto, Vania Dewi. 2016. "Teknik Humor Dalam Film Komedi Yang Dibintangi Oleh Stand Up Comedian”. Jurnal EKomunikasi, 4 (1): 1-2

Sugiyono. 2014. Metode Penelitian Kuantitatif, Kualitatif, dan R\&D. Bandung: Alfabeta.

Sukardi, M. Ighfir, Rawuh Yuda Yuwana, \& Sumarlam. 2016. "Penyimpangan Makna dan Perubahan Konstituen 
Rawuh Yuda Yuwana

dalam Humor Cak Lontong”. Adabiyyat, 15 (2): 110-135

TRANS7 Official .Indonesia Lawak Klub.

Diakses dari <https://www.youtube. com/user/TRANS7indonesia> (JanuariAgustus 2017)
Ullmann, Stephen. 2012. Pengantar

Semantik (Adaptasi Sumarsono).

Yogyakarta: Pustaka Pelajar. 